\title{
Perhitungan Laju Reaksi Neutron Model Perangkat Annular Pada Jenis Reaktor SCWR (Supercritical Water Reactor) Bahan Bakar Thorium
}

\author{
Ismatul Lisa ${ }^{(1)^{*}}$, Yanti Yulianti(1), dan Syafriadi(1) \\ (1) Jurusan Fisika FMIPA Universitas Lampung, \\ Jl.Prof. Dr. Soemantri Brojonegoro No.1 Gedung Meneng Bandar Lampung 35145 \\ *E-mail: Ismatullisa27@gmail.com
}

Diterima (10 Mei 2018), Direvisi (28 Mei 2018)

\begin{abstract}
The calculation of fission reaction rate and capture reaction with and without filters have been done using the REACT of SRAC. The calculation of fission rate on fuel 1 and 2 were 5,39 $\times 10^{-2}$ reaction/ $/ \mathrm{cm}^{3}$ s with filter and $6,35 \times 10^{-2}$ reaction/ $/ \mathrm{cm}^{3} s$ without filter, then of capture reaction rate with filter on fuel 1 and 2 were 2,91 $\times 10^{-2}$ reaction/ $/ \mathrm{cm}^{3}$ s, without filter on fuel 1 was 3,9 $\times 10^{-2}$ reaction $/ \mathrm{cm}^{3}$ s and fuel 2 was $3,78 \times 10^{-2}$ reaction $/ \mathrm{cm}^{3} \mathrm{~s}$. The calculation of capture reaction on cladding with filter was higher than without filter was $2,15 \times 10^{-3}$ reaction/ $\mathrm{cm}^{3}$ s, on moderator with filter was lower than without filter was $3,18 \times$ $10^{-3}$ reaction $/ \mathrm{cm}^{3}$ s. The highest neutron spectrum with $1 \%$ enrichment of experiment 1 in thermal energy was $6,31 \times 10^{-6} \mathrm{MeV}^{-1}$ and in fast energy was 6,44 $\times 10^{-6} \mathrm{MeV}^{-1}$, and decreased constantly. Meanwhile of experiment 2, neutron spectrum in thermal energy was $1,37 \times 10^{-5} \mathrm{MeV}^{-1}$ and in fast energy was 6,91 $\times 10^{-6}$ $\mathrm{MeV}^{-1}$, and decreased significantly from $1 \%$ to $2 \%$ enrichment then decreases constantly until $5 \%$ enrichment.
\end{abstract}

Keywords: thorium,SCWR, neutron reaction rate,neutron spectrum, SRAC.

\begin{abstract}
Abstrak.Telah dilakukan perhitungan laju reaksi fisi dan penangkapan neutron dengan dan tanpa filter menggunakan kode REACT pada program SRAC.Hasil perhitungansaat pengayaan 3\% yang diperoleh menunjukkan nilai laju reaksi fisi pada bahan bakar 1 dan 2 bernilai sama, yaitu $5,39 \times 10^{-2} \mathrm{reaksi} / \mathrm{cm}^{3} \mathrm{~s}$ dengan filter dan $6,35 \times 10^{-2}$ reaksi $/ \mathrm{cm}^{3} \mathrm{~s}$ non filter. Nilai laju reaksi penangkapan dengan filter pada bahan bakar 1 dan 2 juga bernilai sama, yaitu $2,91 \times 10^{-2}$ reaksi $/ \mathrm{cm}^{3} \mathrm{~s}$. Pada non filter berbeda, yaitu 3,90 $\times 10^{-2}$ reaksi $/ \mathrm{cm}^{3} \mathrm{~s}$ pada bahan bakar 1 dan $3,78 \times 10^{-2}$ reaksi $/ \mathrm{cm}^{3} \mathrm{~s}$ pada bahan bakar 2 . Nilai laju reaksi penangkapan pada selongsong dengan filter lebih tinggi daripada non filter yaitu $2,15 \times 10^{-3} \mathrm{reaksi} / \mathrm{cm}^{3} \mathrm{~s}$. Pada moderator dengan filter lebih rendah daripada non filter yaitu $3,18 \times 10^{-3} \mathrm{reaksi} / \mathrm{cm}^{3} \mathrm{~s}$. Spektrum neutron tertinggi pada pengayaan $1 \%$ pada percobaan 1 sebesar 6,31 × 10-6 $\mathrm{Mev}^{-1}$ pada energi termal dan 6,44 $\times 10-6$ $\mathrm{Mev}^{-1}$ pada energi cepat, dan menurun secara konstan seiring ditambahnya nilai pengayaan. Sementara pada percobaan 2 spektrum neutron sebesar 1,37 $\times 10-5 \mathrm{Mev}^{-1}$ pada energi termal dan 6,91 $\times 10-6 \mathrm{Mev}^{-1}$ pada energi cepat, dan menurun secara drastis dari pengayaan $1 \%$ ke $2 \%$ lalu menurun secara konstan sampai $5 \%$.
\end{abstract}

Kata kunci: thorium, SCWR, laju reaksi neutron, spektrum neutron, SRAC.

\section{PENDAHULUAN}

Problema energi merupakan suatu hal yang sedang hangat diperbincangkan saat ini. Cadangan energi fosil yang hanya mampu bertahan sekitar 10-13 tahun mendatang, tidak dapat membawa
Indonesia ke kondisi yang diharapkan di tahun 2045 yakni peningkatan perekonomian Indonesia[1]. Semua ini mengharuskan pentingnya upaya untuk mengembangkan sumber daya energi alternatif yaitu sumber daya energi nuklir dan sumber daya energi terbarukan. 
Teknologi reaktor nuklir yang tersedia saat ini adalah teknologi reaktor nuklir yang menggunakan uranium sebagai bahan bakar utama melalui reaksi fisi U-235 [2]. Reaksi fisi harus berlangsung secara terkendali dalam sebuah reaktor nuklir agar dapat dimanfaatkan sebagai sumber Pembangkit Listrik Tenaga Nuklir (PLTN).

Selain uranium, thorium dapat digunakan sebagai bahan bakar nuklir alternatif. Thorium merupakan bahan fertil yang apabila menyerap netron akan menjadi bahan fisil U-233 yang dalam reaktor nuklir dapat menghasilkan reaksi berantai sehingga dapat digunakan sebagai bahan bakar PLTN. Thorium lebih banyak persediaannya daripada uranium dan lebih murah, membutuhkan lebih sedikit usaha saat pembuatan bahan bakar dan pengolahan pasca bahan bakar bekas, yang berarti pembiyaannya lebih rendah[3]. Fisi dari U-233 ini menghasilkan jumlah energi yang hampir setara dengan U-235 yakni sebesar 172,91 MeV[4].

Thorium adalah logam alami yang bersifat radioaktif, ditemukan pada tahun 1828 oleh Jons Jacob Berzelius seorang kimiawan Swedia. Pada keadaan murni thorium merupakan logam putih keperakan yang berkilau. Namun bila terkontaminasi oksigen, thorium perlahan akan memudar di udara menjadi abu-abu dan akhirnya hitam. Thorium mempunyai titik leleh sekitar $3.300{ }^{\circ} \mathrm{C}$. Selain itu thorium bersifat reaktif dan bereaksi dengan oksigen, hidrogen, halogen dan sulfur. Thorium bereaksi secara lambat terhadap air, namun tidak mudah larut pada hampir semua asam, kecuali asam klorida[5].

Supercritical Water Reactor (SCWR) merupakan jenis reaktor generasi IV yang banyak dikembangkan karena sederhana dalam pembangunannya, efisiensi termal yang tinggi, dan hampir 50 tahun berpengalaman pada industri stasiun energi panas[6]. Meskipun ukuran fisiknya lebih kecil, SCWR mampu menghasilkan energi yang besar[7]. Oleh karena itu, SCWR sangat cocok diaplikasikan di Indonesia.

Di dalam reaktor, reaksi fisi harus dikontrol dengan sangat cermat dan teliti, sehingga dalam perancangannya dibutuhkan analisis neutronik, analisis distribusi laju fisi, dan analisis termohidrolik. Perhitungan laju reaksi fisi sangat penting dilakukan, karena apabila laju reaksi tidak merata dapat menghasilkan pemuncakan daya (power-peaking) yang tidak diinginkan. Produksi energi yang terjadi pada sistem reaktor sangat tergantung pada produksi neutron di teras reaktor tersebut[8].

Analisis pada penelitian ini dilakukan dengan menggunakan program System Reactor Atomic Code (SRAC) yang dikembangkan oleh Japan Atomic Energy Research Institute (JAERI) pada tahun 1978. SRAC digunakan sebagai sistem kode neutronik untuk mensimulasikan perilaku nuklir di dalam teras reaktor[9] .

\section{METODE PENELITIAN}

Penelitian ini dimulai dengan membuat desain reaktor SCWR model perangkat Annulardengan enam pin bahan bakar berbentuk lingkaran. Setelah diperoleh desain reaktor SCWR, selanjutnya menentukan ukuran dari tiap-tiap sel. Kemudian melakukan perhitungan fraksi volume untuk mengetahui persentase setiap material yang digunakan. Besarnya fraksi volume dapat diketahui dari jari-jari tiap sel.

Kemudian menghitung nilai densitas atom dari material yang digunakan dan persentase pengayaan dari kedua bahan bakar reaktor. Densitas atom dapat dihitung dengan persamaan sebagai berikut:

$$
N=\frac{\rho N_{A}}{M}
$$

Dimana, $N=$ densitas atom (atom $\left./ \mathrm{cm}^{3}\right), \rho=$ massa jenis $\left(\mathrm{gr} / \mathrm{cm}^{3}\right), \quad N_{A}=$ bilangan 
Avogadro $\left(6,02 \times 10^{23}\right.$ atom $\left./ \mathrm{mol}\right), M=$ massa molekul (gr/mol).

Selanjutnya dilakukan perhitungan laju reaksi neutron dengan memasukkan nilai densitas atom dan pengayaan bahan bakar pada kode REACT pada program SRAC. Sistem SRAC menghitung laju reaksi menggunakan detektor dengan filter dan detektor tanpa filter dengan persamaan berikut:

$$
R(\vec{r})=\sum_{g=1}^{I G M A X} \Sigma_{x, g} \varphi_{g}(\vec{r})
$$

Dengan, $R=$ laju reaksi neutron (reaksi $/ \mathrm{cm} 3 \mathrm{~s}), \quad \Sigma_{\chi, g}=$ penampang lintang makroskopik $\left(\mathrm{cm}^{-1}\right), \varphi_{g}=$ fluks neutron (neutron $/ \mathrm{cm}^{2} \mathrm{~s}$ ), IGMAX = jumlah grup energi.

$$
R(\vec{r})=\sum_{g=1}^{I G M A X} f_{g} \Sigma_{x, g} \varphi_{g}(\vec{r})
$$

Dimana $f_{g}=$ filter transmisi faktor [9].

\section{HASiL DAN PEMBAHASAN}

\section{Desain Model Perangkat Annular}

Model perangkat annular ditunjukkan pada Gambar 1. Model ini sesuai dengan kode IGT 11 pada SRAC(Okumuraet al., 2002). Angka 1, 3, dan 5 merupakan bahan bakar $1\left(\mathrm{ThUO}_{2}\right)$ dengan luas $3,41695 \mathrm{~cm}^{2}$. Angka 7, 9, dan 11 merupakan bahan bakar $2\left(\mathrm{ThUO}_{2}\right)$ dengan luas $0,43584 \mathrm{~cm}^{2}$. Angka 2, 4, 6, 8, 10, dan 12 merupakan cladding (Zr) dengan luas $0,27893 \mathrm{~cm}^{2}$, angka 13 sampai dengan 27 merupakan moderator atau bahan pendingin $\left(\mathrm{H}_{2} \mathrm{O}\right)$.

Fraksi volume material dan ukuran dari masing-masing sel dalam reaktor SCWR disajikan pada Tabel 1. Persentase jumlah ketiga sel bahan bakar 1 sebesar 6,38\%, ketiga sel bahan bakar 2 sebesar $0,81 \%$, ketiga sel selongsong 1 dan 2 sebesar $0,52 \%$ dan moderator $91,76 \%$. Jumlah persentase dari masing-masing material adalah $100 \%$.

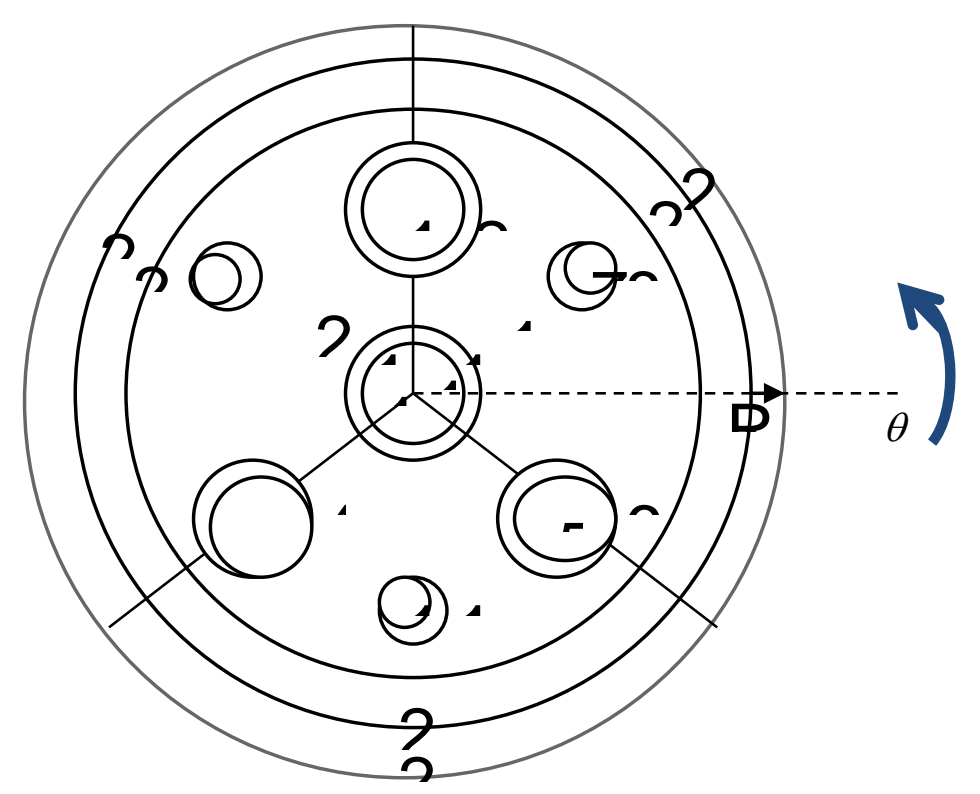

Gambar 1. Desain model perangkat annular dengan pin asimetris (IGT 11).

Tabel 1. Fraksi volume bahan bakar, selongsong dan moderator. 


\begin{tabular}{cccc}
\hline Komponen & Jari-jari $(\mathbf{c m})$ & Area $\left(\mathbf{c m}^{2}\right)$ & Fraksi Volume (\%) \\
\hline Bahan bakar 1 & 0,602 & 3,41695 & 6,3802083 \\
Bahan bakar 2 & 0,215 & 0,43584 & 0,8138021 \\
Selongsong 1 & 0,172 & 0,27893 & 0,5208333 \\
Selongsong 2 & 0,172 & 0,27893 & 0,5208333 \\
Moderator & 4,128 & 49,1448 & 91,764322 \\
\hline
\end{tabular}

\section{Membandingkan Perhitungan Laju Reaksi Neutron Pada Setiap Material}

Perhitungan laju reaksi neutron menujukkan jumlah reaksi neutron dengan material bahan bakar per $\mathrm{cm}^{3}$ per sekon. Program SRAC melakukan perhitungan laju reaksi fisi dan reaksi penangkapan neutron dengan menggunakan detektor neutron dengan filter berbahan
cadmium(Knoll, 1989) dan tanpa filter. Gambar 2dan Gambar 3 menunjukkan perbandingan laju reaksi dengan dan non filter masing-masing material saat dilakukan pengayaan $3 \%$ pada bahan bakar 1 dan bahan bakar 2 .

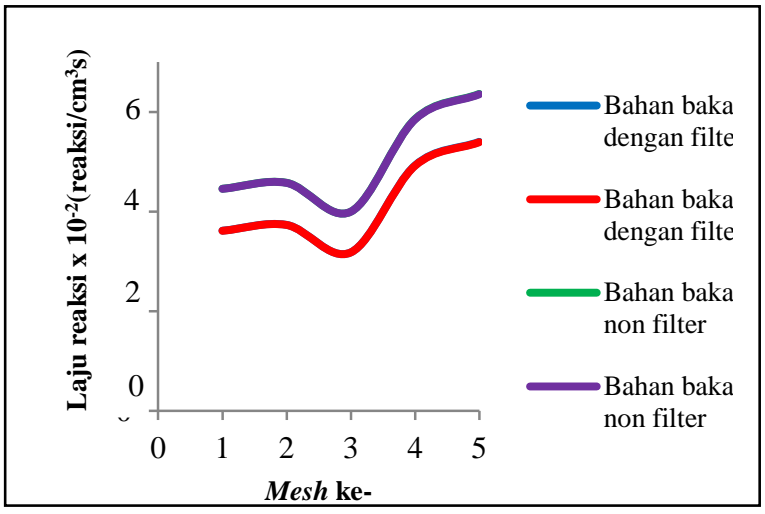

(a.)

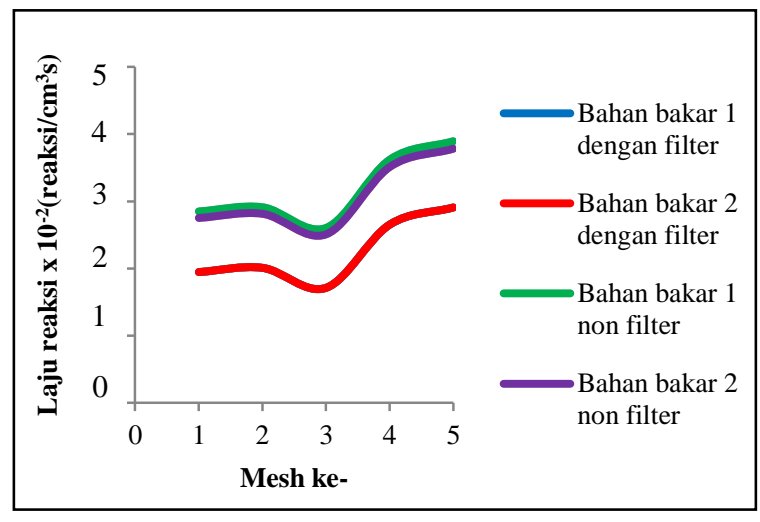

(b.)

Gambar 2. Perbandingan laju reaksi neutron dengan dan non filter bahan bakar 1 dan 2 pada pengayaan 3\% (a.) fisi (b.) penangkapan.

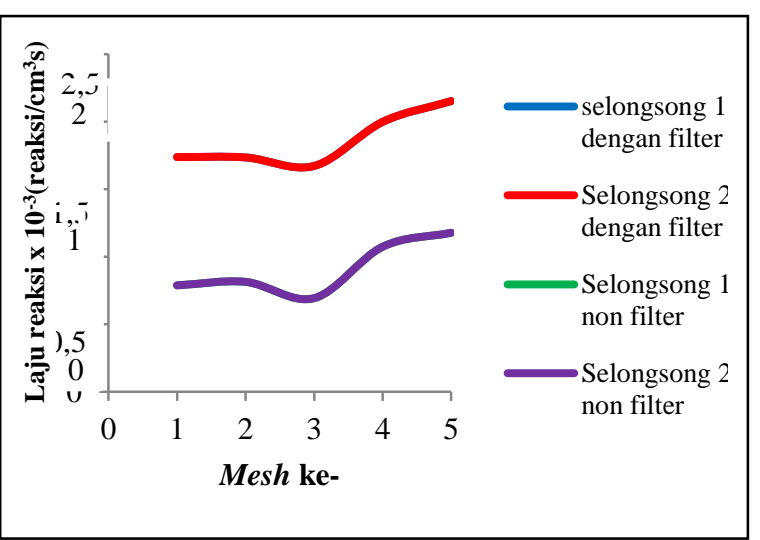

(a.)

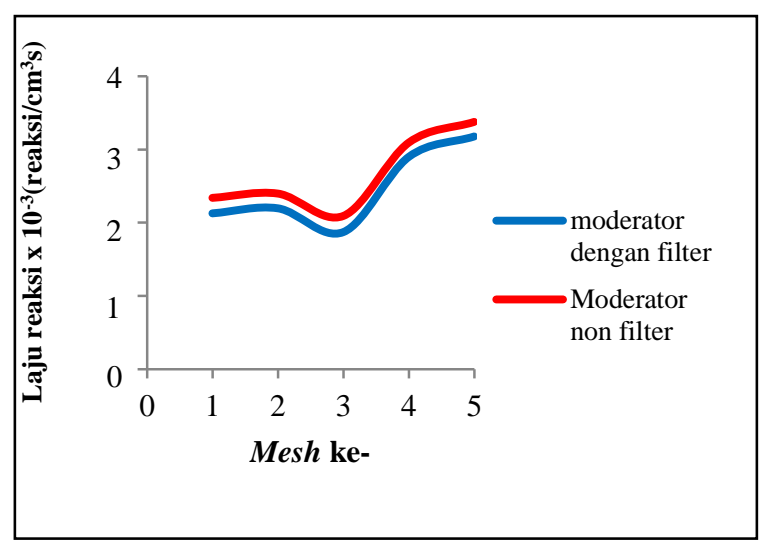

(b.)

Gambar 3. Perbandingan laju reaksi penangkapan neutron dengan dan non filter padapengayaan 3\% (a.) selongsong (b.) moderator. 
Gambar 2 (a) laju reaksi fisi pada bahan bakar. Nilai laju reaksi fisi pada bahan bakar 1 dan 2 dengan (merah dan biru) dan non filter (ungu dan hijau) bernilai samasehingga hanya menampilkan satu garis yang mewakilkan dua nilai laju reaksi. Nilai laju reaksi penangkapan pada bahan bakar 1 dan 2 dengan filter bernilai sama (merah dan biru). Gambar 2(b) laju reaksi penangkapan pada bahan bakar. Nilai laju rekasi pada bahan bakar 1 dan 2 non filter bernilai sedikit berbeda (ungu dan hijau). Dapat dilihat bahwa laju reaksi neutron non filter lebih tinggi daripada dengan filter akibat tidak adanya transmisi filter pada reaksi non filter. Hal ini menunjukkan bahwa perbedaan fraksi volume pada bahan bakar 1 dan 2 tidak mempengaruhi nilai laju reaksi fisi dan penangkapan dengan filter dan sedikit mempengaruhi nilai laju reaksi penangkapan non filter pada pengayaan $3 \%$.

Gambar 3 (a) laju reaksi penangkapan pada selongsong. laju reaksi dengan filter (merah dan biru) lebih tinggi daripada non filter (ungu dan hijau) akibat adanya transmisi filter.Hal ini menunjukkan bahwa perbedaan fraksi volume pada selongsong 1 dan 2 tidak mempengaruhi nilai laju reaksi penangkapan dengan dan non filter pada pengayaan bahan bakar 3\%. Gambar 3(b) laju penangkapan pada moderator. laju reaksi non filter lebih tinggi daripada dengan filter. Hal ini menunjukkan bahwa transmisi filter pada moderator memperkecil nilai laju reaksi penangkapan dengan filter pada pengayaan bahan bakar $3 \%$.

\section{Membandingkan Perhitungan Laju Reaksi Neutron Pada Dua Percobaan}

Pada penelitian ini dilakukan dua percobaan, yakni percobaan pertama dilakukan variasi pengayaan 1 sampai $5 \%$ pada bahan bakar 1 dan pengayaan $3 \%$ pada bahan bakar 2. Sementara percobaan kedua, dilakukan variasi pengayaan 1 sampai $5 \%$ pada bahan bakar 2 dan pengayaan 3\% pada bahan bakar 1. Sedangkan pada selongsong 1, selongsong 2 dan moderator tidak dilakukan perubahan. Pada penelitian ini digunakan nilai laju reaksi pada mesh ke-4 sebab adanya peristiwa tumbukan elastis pada mesh ke-3 yang menyebabkan neutron kehilangan energi sehingga laju reaksi fisi dan penangkapan mengalami penurunan[12]. Lalu, nilai laju reaksi mengalami peningkatan yang cukup tinggi pada mesh ke-4. Tabel berikut menunjukkan perbandingan perhitungan laju reaksi neutron kedua percobaan. Tabel $\mathbf{2}$ dan $\mathbf{3}$ menunjukkan laju reaksi fisi dengan dan non filter bahan bakar 1 pada percobaan 1 meningkat seiring ditambahnya persentase pengayaan namun pada percoban 2 menurun. Sementara laju reaksi fisi dengan dan non bahan bakar 2 pada percobaan 1 menurun seiring ditambahnya nilai persentase pengayaan namun pada percobaan 2 meningkat. Hal ini menunjukkan bahwa persentase pengayaan bahan bakar mempengaruhi nilai laju reaksi fisi dengan dan non filter.

Tabel 2. Perbandingan laju reaksi fisi dengan filter bahan bakar pada mesh ke-4.

\begin{tabular}{|c|c|c|c|c|}
\hline \multirow[b]{2}{*}{$\begin{array}{c}\text { Pengayaan } \\
(\%)\end{array}$} & \multicolumn{2}{|c|}{ Percobaan 1} & \multicolumn{2}{|c|}{ Percobaan 2} \\
\hline & $\begin{array}{l}\text { Bahan bakar } 1 \text { ( } \\
\left.1^{-2} \text { reaksi//.cm }{ }^{3} \mathrm{~s}\right)\end{array}$ & $\begin{array}{c}\text { Bahan bakar } 2 \\
\left(\times 10^{-2}\right. \\
\text { reaksi/cm } \\
\end{array}$ & $\begin{array}{c}\text { Bahan bakar } 1 \\
\left(\times 10^{-2}\right. \\
\left.\text { reaksi/cm }{ }^{3} \mathrm{~s}\right) \\
\end{array}$ & $\begin{array}{c}\text { Bahan bakar } 2 \\
\left(\times 10^{-2}\right. \\
\left.\text { reaksi } / \mathrm{cm}^{3} \mathrm{~s}\right) \\
\end{array}$ \\
\hline 1 & 1,77 & 5,30 & 11,3 & 3,77 \\
\hline 2 & 3,40 & 5,10 & 6,73 & 4,49 \\
\hline 3 & 4,92 & 4,92 & 4,92 & 4,92 \\
\hline 4 & 6,35 & 4,76 & 3,95 & 5,26 \\
\hline 5 & 7,69 & 4,62 & 3,34 & 5,56 \\
\hline
\end{tabular}


Tabel 3. Perbandingan laju reaksi fisi non filter bahan bakar pada mesh ke-4.

\begin{tabular}{|c|c|c|c|c|}
\hline \multirow[b]{2}{*}{$\begin{array}{c}\text { Pengayaan } \\
(\%)\end{array}$} & \multicolumn{2}{|c|}{ Percobaan 1} & \multicolumn{2}{|c|}{ Percobaan 2} \\
\hline & $\begin{array}{l}\text { Bahan bakar } 1 \text { ( } \\
1^{-2} \text { reaksi//.cm }{ }^{3} \text { s) }\end{array}$ & $\begin{array}{c}\text { Bahan bakar } 2 \\
\left(\times 10^{-2}\right. \\
\left.\text { reaksi } / \mathrm{cm}^{3} \mathrm{~s}\right) \\
\end{array}$ & $\begin{array}{c}\text { Bahan bakar } 1 \\
\left(\times 1^{-2}\right. \\
\left.\text { reaksi } / \mathrm{cm}^{3} \mathrm{~s}\right) \\
\end{array}$ & $\begin{array}{c}\text { Bahan bakar } 2 \\
\left(\times 1^{-2}\right. \\
\left.\text { reaksi } / \mathrm{cm}^{3} \mathrm{~s}\right)\end{array}$ \\
\hline 1 & 2,11 & 6,26 & 12,7 & 4,28 \\
\hline 2 & 4,05 & 6,04 & 7,82 & 5,22 \\
\hline 3 & 5,86 & 5,85 & 5,86 & 5,85 \\
\hline 4 & 7,56 & 5,67 & 4,79 & 6,36 \\
\hline 5 & 9,18 & 5,52 & 4,12 & 6,82 \\
\hline
\end{tabular}

Tabel 4. Perbandingan laju reaksi penangkapan dengan filter bahan bakar pada mesh ke-4.

\begin{tabular}{|c|c|c|c|c|}
\hline \multirow[b]{2}{*}{$\begin{array}{c}\text { Pengayaan } \\
(\%)\end{array}$} & \multicolumn{2}{|c|}{ Percobaan 1} & \multicolumn{2}{|c|}{ Percobaan 2} \\
\hline & 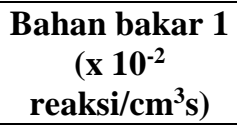 & $\begin{array}{c}\text { Bahan bakar } 2 \\
\left(\times 10^{-2}\right. \\
\left.\text { reaksi/cm }{ }^{3} \mathrm{~s}\right)\end{array}$ & $\begin{array}{c}\text { Bahan bakar } 1 \\
\left(\times 10^{-2}\right. \\
\left.\text { reaksi } / \mathrm{cm}^{3} \mathrm{~s}\right)\end{array}$ & $\begin{array}{c}\text { Bahan bakar } 2 \\
\left(\times 1^{-2}\right. \\
\left.\text { reaksi } / \mathrm{cm}^{3} \mathrm{~s}\right) \\
\end{array}$ \\
\hline 1 & 2,56 & 2,86 & 6,10 & 5,48 \\
\hline 2 & 2,61 & 2,75 & 3,63 & 3,44 \\
\hline 3 & 2,65 & 2,65 & 2,65 & 2,65 \\
\hline 4 & 2,70 & 2,56 & 2,13 & 2,24 \\
\hline 5 & 2,74 & 2,49 & 1,80 & 1,98 \\
\hline
\end{tabular}

Tabel 5. Perbandingan laju reaksi penangkapan non filter bahan bakar pada mesh ke-4.

\begin{tabular}{|c|c|c|c|c|}
\hline \multirow[b]{2}{*}{$\begin{array}{c}\text { Pengayaan } \\
(\%)\end{array}$} & \multicolumn{2}{|c|}{ Percobaan 1} & \multicolumn{2}{|c|}{ Percobaan 2} \\
\hline & $\begin{array}{l}\text { Bahan bakar } 1 \text { ( } \\
10^{-2} \text { reaksi } / \mathrm{cm}^{3} \mathrm{~s}\end{array}$ & $\begin{array}{c}\text { Bahan bakar } 2 \\
\left(\times 1^{-2}\right. \\
\left.\text { reaksi/cm } \text { cm }^{3}\right)\end{array}$ & $\begin{array}{c}\text { Bahan bakar } 1 \\
\left(\mathbf{1} \mathbf{1 0}^{-2}\right. \\
\left.\text { reaksi/cm² }{ }^{3}\right)\end{array}$ & $\begin{array}{c}\text { Bahan bakar } 2 \\
\left(\times 10^{-2}\right. \\
\left.\text { reaksi } / \mathrm{cm}^{3} \mathrm{~s}\right)\end{array}$ \\
\hline 1 & 3,46 & 3,74 & 7,50 & 6,58 \\
\hline 2 & 3,54 & 3,62 & 4,73 & 4,37 \\
\hline 3 & 3,62 & 3,51 & 3,62 & 3,51 \\
\hline 4 & 3,70 & 3,42 & 3,02 & 3,07 \\
\hline 5 & 3,78 & 3,33 & 2,64 & 2,80 \\
\hline
\end{tabular}

Tabel 4 dan 5 menunjukkan laju reaksi penangkapan dengan dan non filter bahan bakar 1 pada percobaan 1 meningkat seiring ditambahnya persentase pengayaan namun pada percoban 2 menurun. Sementara laju reaksi bahan bakar 2 pada percobaan 1 dan percobaan 2 menurun seiring ditambahnya nilai persentase pengayaan. Hal ini menunjukkan bahwa persentase pengayaan bahan bakar mempengaruhi nilai laju reaksi penangkapan dengan dan non filter.

Tabel 6. Perbandingan laju reaksi penangkapan dengan filter selongsong pada mesh ke-4.

\begin{tabular}{|c|c|c|c|c|}
\hline \multirow[b]{2}{*}{$\begin{array}{c}\text { Pengayaan } \\
(\%)\end{array}$} & \multicolumn{2}{|c|}{ Percobaan 1} & \multicolumn{2}{|c|}{ Percobaan 2} \\
\hline & $\begin{array}{l}\text { Selongsong } 1 \\
\left(\times 1^{-3}\right. \\
\left.\text { reaksi/cm } / \mathrm{cm}^{3} \mathrm{~s}\right)\end{array}$ & 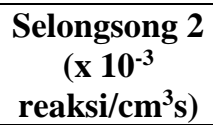 & $\begin{array}{l}\text { Selongsong } 1 \\
\left(\times 1^{-3}\right. \\
\text { reaksi/cm } \\
\text { 's })\end{array}$ & $\begin{array}{l}\text { Selongsong } 2 \\
\left(\times 1^{-3}\right. \\
\left.\text { reaksi } / \mathrm{cm}^{3} \mathrm{~s}\right)\end{array}$ \\
\hline 1 & 1,16 & 1,16 & 2,47 & 2,47 \\
\hline 2 & 1,11 & 1,11 & 1,47 & 1,47 \\
\hline 3 & 1,07 & 1,07 & 1,07 & 1,07 \\
\hline 4 & 1,04 & 1,04 & 0,86 & 0,86 \\
\hline 5 & 1,01 & 1,01 & 0,73 & 0,73 \\
\hline
\end{tabular}


Tabel 7. Perbandingan laju reaksi penangkapan non filter selongsong pada mesh ke-4.

\begin{tabular}{|c|c|c|c|c|}
\hline \multirow[b]{2}{*}{$\begin{array}{c}\text { Pengayaan } \\
(\%)\end{array}$} & \multicolumn{2}{|c|}{ Percobaan 1} & \multicolumn{2}{|c|}{ Percobaan 2} \\
\hline & $\begin{array}{c}\text { Selongsong } 1 \\
\left(\times 1^{-3}\right. \\
\left.\text { reaksi/cm } / \mathrm{cm}^{3} \mathrm{~s}\right)\end{array}$ & $\begin{array}{l}\text { Selongsong } 2 \\
\left(\times 1^{-3}\right. \\
\left.\text { reaksi/cm }{ }^{3} \mathrm{~s}\right)\end{array}$ & $\begin{array}{l}\text { Selongsong } 1 \\
\left(\times 1^{-3}\right. \\
\left.\text { reaksi/cm }{ }^{3} \mathrm{~s}\right)\end{array}$ & $\begin{array}{l}\text { Selongsong } 2 \\
\left(\times 1^{-3}\right. \\
\left.\text { reaksi } / \mathrm{cm}^{3} \mathrm{~s}\right)\end{array}$ \\
\hline 1 & 2,10 & 2,10 & 3,77 & 3,77 \\
\hline 2 & 2,05 & 2,05 & 2,51 & 2,51 \\
\hline 3 & 2,00 & 2,00 & 2,00 & 2,00 \\
\hline 4 & 1,95 & 1,95 & 1,72 & 1,72 \\
\hline 5 & 1,91 & 1,91 & 1,54 & 1,54 \\
\hline
\end{tabular}

Tabel 8. Perbandingan laju reaksi penangkapan dengan filter moderator pada mesh ke-4.

\begin{tabular}{|c|c|c|c|c|}
\hline \multirow{2}{*}{ Pengayaan (\%) } & \multicolumn{2}{|c|}{ dengan filter $\left(\times 1^{-3}\right.$ reaksi/ $\left.\mathrm{cm}^{3} \mathrm{~s}\right)$} & \multicolumn{2}{|c|}{ non filter $\left(\times 10^{-3}\right.$ reaksi $\left./ \mathrm{cm}^{3} \mathrm{~s}\right)$} \\
\hline & Percobaan 1 & Percobaan 2 & Percobaan 1 & Percobaan 2 \\
\hline 1 & 3,12 & 7,17 & 3,32 & 7,47 \\
\hline 2 & 3,00 & 4,31 & 3,20 & 4,54 \\
\hline 3 & 2,90 & 3,18 & 3,09 & 3,37 \\
\hline 4 & 2,80 & 2,57 & 2,99 & 2,75 \\
\hline 5 & 2,72 & 2,18 & 2,91 & 2,35 \\
\hline
\end{tabular}

Tabel 6 dan 7 menunjukkan laju reaksi penangkapan dengan dan non filter selongsong 1 sama dengan nilai laju reaksi penangkapan selongsong 2 baik pada percobaan 1 maupun percobaan 2. Pada percobaan 1 dan 2, nilai laju reaksi penangkapan dengan dan non filter menurun seiring ditambahnya persentase pengayaan. Hal ini menunjukkan bahwa persentase pengayaan bahan bakar mempengaruhi nilai laju reaksi penangkapan dengan dan non filter pada selongsong.

Tabel 8 menunjukkan laju reaksi penangkapan dengan dan non filter moderator pada percobaan 1 menurun secara konstan seiring ditambahnya persentase pengayaan dan percobaan 2 menurun secara drastis dari pengayaan $1 \%$ ke $2 \%$ lalu mulai konstan seiring ditambahnya persentase pengayaan. Nilai laju reaksi penangkapan dengan dan non filter pada percobaan 2 memiliki selisih yang lebih besar terhadap percobaan 1. Hal ini menunjukkan bahwa persentase pengayaan bahan bakar mempengaruhi nilai laju reaksi penangkapan dengan dan non filter pada moderator.

\section{Perhitungan Energi dan Spektrum Neutron}

Spektrum neutron merupakan besaran yang menyatakan jumlah neutron persatuan energi. Secara umum, energi neutron akan terdistribusi atas tiga kelompok besar, yakni termal (I), epitermal (II) dan cepat (III). Spektrum neutron dari reaktor SCWR pada penelitian ini ditunjukkan dalam kurva pada Gambar 4. 


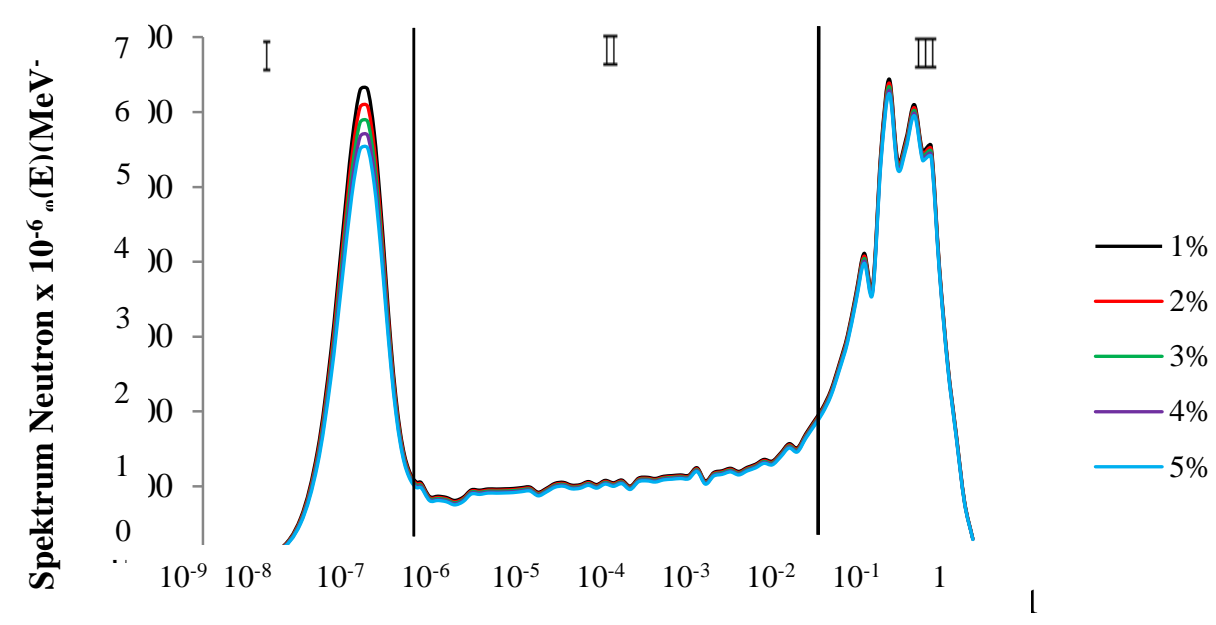

Kelompok Energi (MeV)

(a.)

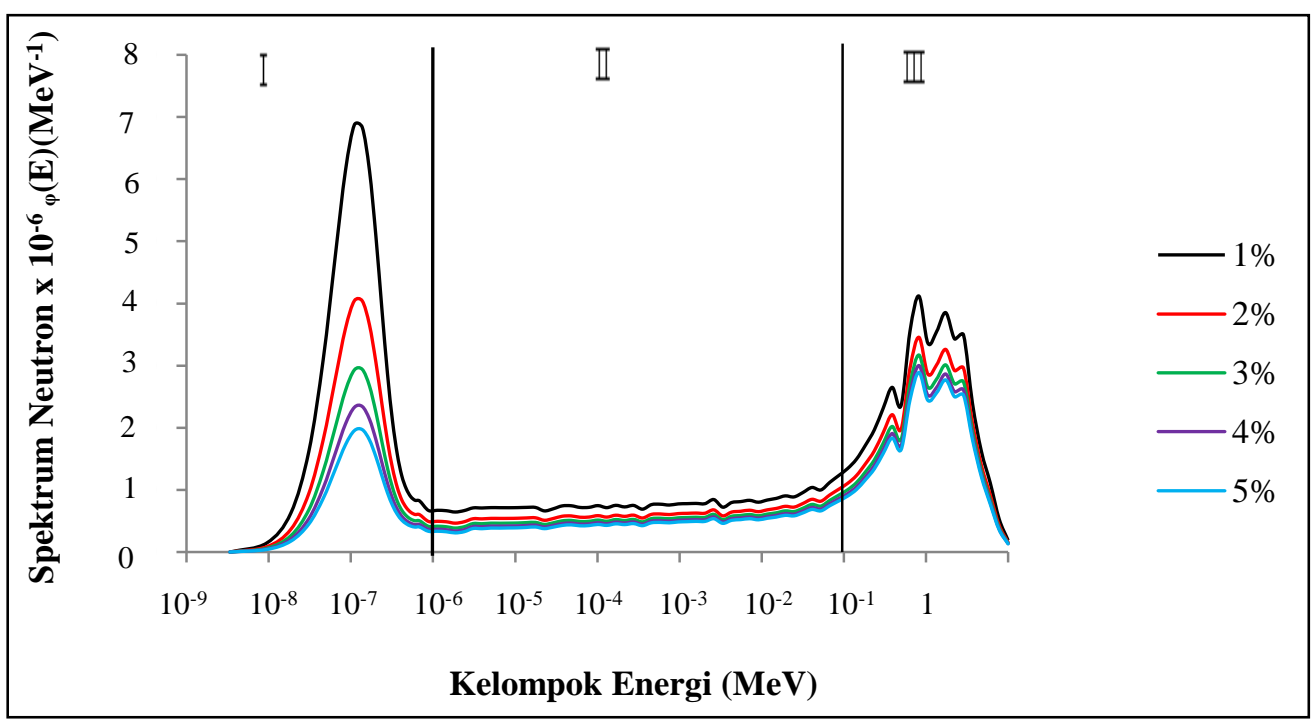

(b.)

Gambar 4. Hubungan energi terhadap spektrum neutron pada (a.) percobaan 1 (b.) percobaan 2

Berdasarkan gambar 4 (a.) Spektrum neutron pada percobaan 1. Pada daerah I (Termal) spektrum neutron menurun secara konstan dari pengayaan 1 sampai 5\% dengan nilai puncak tertinggi pada pengayaan $1 \%$ sebesar $6,44 \times 10^{-6} \mathrm{MeV}^{-1}$, $2 \%$ sebesar $6,39 \times 10^{-6} \mathrm{MeV}^{-1}, 3 \%$ sebesar $6,34 \times 10^{-6} \mathrm{MeV}^{-1}, 4 \%$ sebesar6,29 $\times 10^{-6}$ $\mathrm{MeV}^{-1}$, dan $5 \%$ sebesar6,25 $\times 10^{-6} \mathrm{MeV}^{-1}$. Pada daerah II (epitermal) tidak memperlihatkan ciri distribusi spektrum neutron per energi, melainkan agak mendatar. Hal ini menunjukkan bahwa terjadi keseimbangan antara proses perlambatan neutron (yang akan menghasilkan spektrum 1/E) dengan proses penangkapan dan fisi neutron (yang akan menurunkan populsai neutron). Pada daerah III (cepat) nilai puncak maksimum spektrum neutron terjadi pada pengayaan $1 \%$ yakni sebesar $6,44 \times 10^{-6} \mathrm{MeV}^{-1}$.

Gambar 4 (b.) Spektrum neutron pada percobaan 2. Pada daerah I (Termal) spektrum neutron menurun secara drastis dari pengayaan $1 \%$ sebesar $1,37 \times 10^{-5}$ $\mathrm{MeV}^{-1}$, lalu 2\% sebesar 8,09 $\times 10^{-6} \mathrm{MeV}^{-1}$, 
kemudian menurun secara konstan pada pengayaan $3 \%$ sebesar $6,34 \times 10^{-6} \mathrm{MeV}^{-1}$, $4 \%$ sebesar $6,00 \times 10^{-6} \mathrm{MeV}^{-1}$, dan $5 \%$ sebesar 5,78 $\times 10^{-6} \mathrm{MeV}^{-1}$.Pada daerah II (epitermal) tidak memperlihatkan ciri distribusi spektrum neutron per energi, melainkan agak mendatar. Hal ini menunjukkan bahwa terjadi keseimbangan antara proses perlambatan neutron (yang akan menghasilkan spektrum 1/E) dengan proses penangkapan dan fisi neutron (yang akan menurunkan populsai neutron). Pada daerah III (cepat) nilai puncak maksimum spektrum neutron terjadi pada pengayaan $1 \%$ yakni sebesar $8,24 \times 10^{-6} \mathrm{MeV}^{-1}[13]$.

\section{KESIMPULAN}

Nilai laju reaksi fisi pada bahan bakar 1 dan 2 saat pengayaan $3 \%$, yaitu $5,39 \times 10^{-2}$ reaksi $/ \mathrm{cm}^{3} \mathrm{~s}$ dengan filter dan $6,35 \times 10^{-2}$ reaksi $/ \mathrm{cm}^{3} \mathrm{~s}$ non filter. Nilai laju reaksi penangkapan dengan filter pada bahan bakar 1 dan 2 , yaitu $2,91 \times 10^{-2} \mathrm{reaksi} / \mathrm{cm}^{3} \mathrm{~s}$. Sementara pada non filter, yaitu 3,90 $\times 10^{-2}$ reaksi $/ \mathrm{cm}^{3}$ s pada bahan bakar 1 dan $3,78 \times$ $10^{-2}$ reaksi $/ \mathrm{cm}^{3} \mathrm{~s}$ pada bahan bakar 2 . Nilai laju reaksi penangkapan pada selongsong dengan filter lebih tinggi daripada non filter saat pengayaan $3 \%$ yaitu $2,15 \times 10^{-3}$ reaksi $/ \mathrm{cm}^{3}$ s. Pada moderator non filter lebih tinggi daripada dengan filter yaitu $3,37 \times$ $10^{-3}$ reaksi $/ \mathrm{cm}^{3} \mathrm{~s}$. Laju reaksi fisi dengan dan non filter saat pengayaan $1-5 \%$ bahan bakar 1 meningkat pada percobaan 1 dan menurun pada percobaan 2, namun sebaliknya pada bahan bakar 2. Laju reaksi penangkapan dengan filter saat pengayaan $1-5 \%$ bahan bakar 1 meningkat pada percobaan 1 dan percobaan 2, namun sebaliknya pada bahan bakar 2. Sementara laju reaksi penangkapan non filter bahan bakar 1 meningkat pada percobaan 1 dan menurun pada percobaan 2. Sementara bahan bakar 2 menurun pada percobaan 1 dan percobaan 2. Laju reaksi penangkapan dengan dan non filter saat pengayaan 1-5\% selongsong 1 dan 2 dan moderator pada percobaan 2 lebih besar daripada percobaan 1. Pada percobaan 1 dan 2 spektrum neutron tertinggi pada pengayaan $1 \%$ sebesar 6,31 × 10-6 $\mathrm{Mev}^{-1}$ pada energi termal dan $6,44 \times 10-6 \mathrm{Mev}^{-1}$ pada energi cepat. Lalu menurun secara konstan seiring ditambahnya nilai pengayaan. Sementara pada percobaan 2 spektrum neutron sebesar $1,37 \times 10-5 \mathrm{Mev}^{-1}$ pada energi termal dan $6,91 \times 10-6 \mathrm{Mev}^{-1}$ pada energi cepat. Lalu menurun secara drastis dari pengayaan $1 \%$ ke $2 \%$ lalu menurun secara konstan sampai $5 \%$.

\section{DAFTAR PUSTAKA}

[1] ESDM, "Sektor Energi Sudah Saatnya Menjadi Penggerak Ekonomi Indonesia," 2018.

[2] J. J. Deuderstadt and L. J. Hamilton, "Nuclear Reactor Analysis." pp. 447-460, 1976.

[3] J. N. Wilson et al., "Economy of uranium resources in a threecomponent reactor fleet with mixed thorium/uranium fuel cycles," Ann. Nucl. Energy, vol. 36, no. 3, pp. 404-408, 2009.

[4] Nuclear World, "Outline History of Nuclear Energy,” 2018.

[5] A. A. M. Elkhadrawi, "Thorium Based Nuclear Reactors," pp. 1-51, 2008.

[6] J. Buongiorno and P. MacDonald, "Supercritical water reactor (SCWR)," ... Dev. SCWR US, ..., vol. 240, pp. 1-38, 2003.

[7] G. Tsiklauri, R. Talbert, B. Schmitt, G. Filippov, R. Bogoyavlensky, and E. Grishanin, "Supercritical steam cycle for nuclear power plant," Nucl. Eng. Des., vol. 235, no. 15, pp. 1651-1664, 2005.

[8] R. Martha, M. A. Shafii, and Afdal, "ANALISIS LAJU REAKSI 
NEUTRON DALAM SEL BAHAN BAKAR NUKLIR PADA REAKTOR CEPAT," vol. 8, no. 2, pp. 70-77, 2016.

[9] K. OKUMURA, T. KUGO, K. KANEKO, and K. TSUCHIHASHI, "SRAC (Ver. 2002); The comprehensive neutronics calculation code system - Vol.1 General Description and Input Instruction -," vol. 1, 2002.

[10] lusiana B. Turnip, S. Handani, and S. Mulyadi, "PENGARUH PENAMBAHAN INHIBITOR EKSTRAK KULIT BUAH

\section{MANGGIS \\ TERHADAP} PENURUNAN LAJU KOROSI BAJA ST-37 Lusiana Br Turnip, Sri Handani , Sri Mulyadi," J. Fis. Unand, vol. 4, no. 2, pp. 144-149, 2015.

[11] G. E. Knoll and J. Wiley, Radiation Detection and Measurement. 1989.

[12] S. Bell, George I; Glasstone, "Nuclear ReactorTheory," vol. 6, pp. 68-74, 1970.

[13] P. Ilham Yazid, "Perhitungan Spektrum Energi Fluks Neutron Reaktor TRIGA Bandung." p. Vol. IV, Edisi Khusus 3, 2003. 